\title{
Leprosy mimicking rheumatoid vasculitis with scleromalacia perforans
}

\author{
Manesh Manoj (10 , Urmila Dhakad
}

Department of Rheumatology, King George's Medical University, Lucknow, India

\section{Correspondence to} Dr Manesh Manoj; maneshind@gmail.com

Accepted 15 June 2020

\section{DESCRIPTION}

A 38-year-old woman presented with a history of symmetrical polyarthritis since 3 years, occasional pain in both eyes since 6 months and diminution of vision since 2 months. Patient also reported gradually increasing paraesthesia over both hands and feet since 1 month. On examination, she had symmetrical polyarthritis of small and large joints with correctable swan-neck deformities, vague diminution of sensation over both hands and feet and ocular features characteristic of scleromalacia perforans (figure 1). ${ }^{1}$ Investigations revealed the following: haemoglobin: $97 \mathrm{~g} / \mathrm{L}$; total leucocyte count: $7.3 \times 10^{9} / \mathrm{L}$; platelet count: $300 \times 10^{9} / \mathrm{L}$; erythrocyte sedimentation rate: $39 \mathrm{~mm}$ by Westergren method (first hour); C-reactive protein: 11 $\mathrm{mg} / \mathrm{L}(0-6 \mathrm{mg} / \mathrm{L})$; rheumatoid factor (RF): $25 \mathrm{U} /$ $\mathrm{mL}(<20 \mathrm{U} / \mathrm{mL})$; anti-cyclic citrullinated protein (ACPA): negative; anti-MPO (myeloperoxidase) and anti-PR3 (proteinase-3): negative; anti-nuclear antibody: negative; HIV (human immunodeficiency virus), HbsAg (hepatitis B surface antigen) and anti-HCV (hepatitis $\mathrm{C}$ virus): non-reactive; urine examination: normal; thyroid function: normal; X-ray of hands: mild juxta-articular osteopenia. Nerve conduction studies detected mononeuritis multiplex, including involvement of bilateral sural nerves. The ophthalmologist confirmed scleromalacia perforans along with secondary glaucomatous optic atrophy. A sural nerve biopsy for histopathological examination was also done.

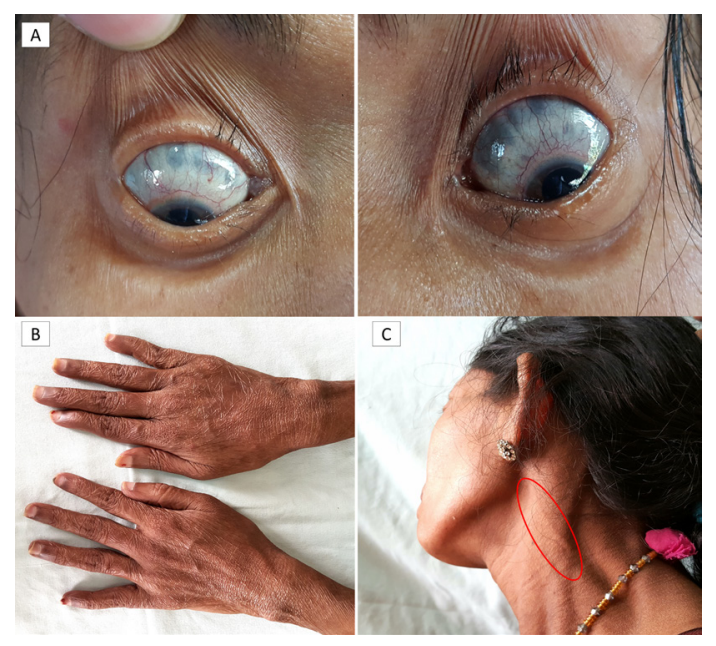

Figure 1 Eyes showing bilateral scleromalacia perforans (A); hands showing swan-neck deformities (B) and thickened, tender great auricular nerve highlighted (C).

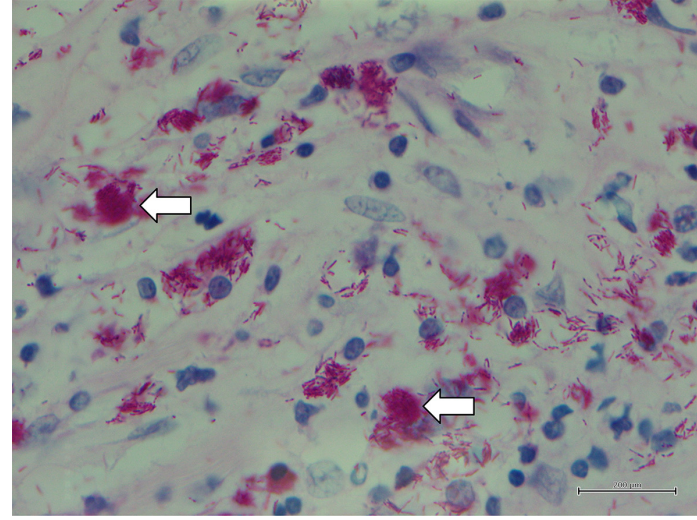

Figure 2 Sural nerve biopsy showing globi of lepra bacilli (white arrows).

In view of polyarthritis, scleromalacia perforans with worsening ocular symptoms and mononeuritis multiplex, a diagnosis of rheumatoid arthritis (RA) and rheumatoid vasculitis with scleromalacia perforans versus undifferentiated vasculitis was considered and she was given pulse intravenous methylprednisolone $(1 \mathrm{~g} /$ day $\times 3$ doses $)$ followed by $1 \mathrm{mg} / \mathrm{kg} /$ day prednisolone and pulse intravenous

\section{Patient's perspective}

I have consulted several doctors in multiple places for my problem, but my issues have progressed in spite of treatment. A diagnosis of leprosy was never considered previously and I was told I have a rheumatological disorder. It is unfortunate that my eye sight has decreased irreversibly and more so because it could have been prevented if it had been diagnosed earlier.

Learning points

Scleromalacia perforans can be a rare but potentially grave manifestation of leprosy.

- Leprosy can mimic a number of rheumatological disorders and needs to be considered in the differential diagnosis of any patient presenting with arthritis (usually oligoarticular), especially in endemic areas.

- Low titre rheumatoid factor positivity with anti-cyclic citrullinated protein negativity in a patient of arthritis should stimulate the treating physician to search for other rheumatological and infectious causes. 
cyclophosphamide was planned. Meanwhile, her sural nerve biopsy report returned revealing lepromatous leprosy with bacillary index $6+$ (figure 2). On re-examination, she was found to have a thickened, slightly tender left great auricular nerve (figure 1), though none of the other peripheral nerves appeared thickened clinically. She also did not have any features suggestive of erythema nodosum leprosum. Treatment with multidrug anti-leprosy therapy was initiated along with tapering of steroids and on follow-up, her arthritis had subsided but vision remained the same.

Hansen's disease or leprosy is almost exclusively seen in developing countries with $80 \%$ of the cases being reported from India, Nepal, Myanmar, China, Indonesia, Brazil and Nigeria. With a large immigrant population, some developed countries have also reported cases. It can present with a multitude of symptoms and has been known to mimic a number of diseases such as RA, spondyloarthropathy, reactive arthritis, psoriatic arthritis, vasculitis, sarcoidosis, gout and can also cause neuropathic joints. ${ }^{2}$ During the initial evaluation in a patient with a poly-articular presentation of the lepromatous spectrum of leprosy, subtle signs of the disease may be missed and a mistaken diagnosis of RA may be made. This is further complicated by the occurrence of RF as well as ACPA positivity in a number of cases. ${ }^{2}$ Scleromalacia perforans has not been previously reported to be associated with leprosy. Even in endemic areas, diagnosis of leprosy may be delayed due to the indolent nature of infection and its various, not infrequent, atypical presentations.

Contributors MM contributed to conception and design, drafting the article, reviewing published literature and was involved in management of the case. UD contributed to final critical appraisal of the article, reviewing the literature and was involved in management of the case.

Funding The authors have not declared a specific grant for this research from any funding agency in the public, commercial or not-for-profit sectors.

Competing interests None declared.

Patient consent for publication Obtained.

Provenance and peer review Not commissioned; externally peer reviewed.

ORCID iD

Manesh Manoj http://orcid.org/0000-0002-4031-136X

\section{REFERENCES}

1 Okhravi N, Odufuwa B, McCluskey P, et al. Scleritis. Surv Ophthalmol 2005;50:351-63.

2 Wakhlu A, Sawlani K, Himanshu D. Rheumatological manifestations of Hansen's disease. Indian J Rheumatol 2018;13:14-19.

Copyright 2020 BMJ Publishing Group. All rights reserved. For permission to reuse any of this content visit

https://www.bmj.com/company/products-services/rights-and-licensing/permissions/

BMJ Case Report Fellows may re-use this article for personal use and teaching without any further permission.

Become a Fellow of BMJ Case Reports today and you can:

- Submit as many cases as you like

- Enjoy fast sympathetic peer review and rapid publication of accepted articles

- Access all the published articles

Re-use any of the published material for personal use and teaching without further permission

Customer Service

If you have any further queries about your subscription, please contact our customer services team on +44 (0) 2071111105 or via email at support@bmj.com.

Visit casereports.bmj.com for more articles like this and to become a Fellow 